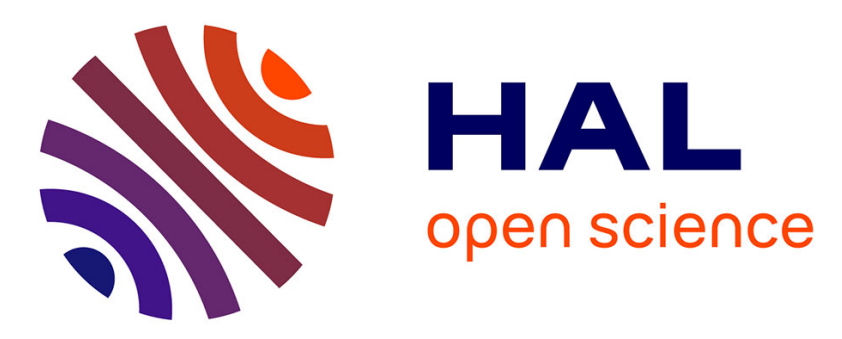

\title{
Author's response to the Letter to the Editor of Tfelt-Hansen
}

Ana Macedo, Magí Farré, Josep-E. Baños

\section{To cite this version:}

Ana Macedo, Magí Farré, Josep-E. Baños. Author's response to the Letter to the Editor of TfeltHansen. European Journal of Clinical Pharmacology, 2010, pp.645-646. 10.1007/s00228-010-0954-7 . hal-00643028

\section{HAL Id: hal-00643028 \\ https://hal.science/hal-00643028}

Submitted on 21 Nov 2011

HAL is a multi-disciplinary open access archive for the deposit and dissemination of scientific research documents, whether they are published or not. The documents may come from teaching and research institutions in France or abroad, or from public or private research centers.
L'archive ouverte pluridisciplinaire $\mathbf{H A L}$, est destinée au dépôt et à la diffusion de documents scientifiques de niveau recherche, publiés ou non, émanant des établissements d'enseignement et de recherche français ou étrangers, des laboratoires publics ou privés. 
Author's response to the Letter to the Editor of Tfelt-Hansen [Ms. ID EJCP-2010-0345].

Ana Macedo, Magí Farré, Josep-E. Baños

A. Macedo, M. Farré

Department of Pharmacology, Therapeutics and Toxicology, Universitat Autònoma de Barcelona, Bellaterra, Spain

M. Farré

Human Pharmacology and Neurosciences, Institut de Recerca Hopsital del Mar (IMIM, Parc de Salut Mar), Barcelona, Spain

Josep-E. Baños (correspondence)

Department of Experimental and Health Sciences, Universitat Pompeu Fabra, Dr. Aiguader 88. 08003 Barcelona, Spain; e-mail: josepeladi.banos@upf.edu; Tel.: +34-93-3160865 
To the editor of European Journal of Clinical Pharmacology

Sir,

We have read with attention the letter of Dr. Tfelt-Hansen regarding our article published in the journal which considered the placebo effect in migraine using meta-analytic techniques ${ }^{1}$. We consider that his comments will help to clarify some of the topics included in our paper. However, we would like to comment some specific points to improve the understanding of our contributions by future readers.

Tfelt-Hansen raises some worries about the definition of headache relief. He states the need of accepting that headache relief should be defined as the decrease in its intensity from moderate (2) or severe (3) to none (0) or mild (1). In fact, in our article we wrote that 'pain relief means a pain reduction higher than $50 \%$ ". In the case of severe pain, a pain reduction of $50 \%$ is a decrease in headache intensity from severe (3) to mild (1) or none (0). For moderate pain, a decrease in headache intensity to mild (1) or none (0) is considered as a success. Therefore, we consider that our definition of "higher of $50 \%$ " is not different from the suggested by Tfelt-Hansen. However, we accept that his definition is clearer than us and also according the Guideline of EMEA for the investigation of medicinal products for the treatment of migraine ${ }^{2}$ and the International Headache Society Clinical Trials Subcommittee ${ }^{3}$. But, for practical purposes, it is almost equivalent.

The author also suggests that pain free at $2 \mathrm{~h}$ is increasingly used as primary efficacy measure. We fully agree with that point of view. In fact, in all tables of our article ${ }^{1}$ we showed pain free and pain relief variables to give the readers the possibility of comparing both of them. The first can be considered as a hard outcome and the second as a soft outcome. However, it is unquestionable that the main objective of treatment should be to leave patients pain free but pain relief can not be considered as a minor issue in clinical practice. As expected, the magnitude of placebo effect was higher when the last was used and decreased when the latter was considered. Unfortunately, although pain free is desirable it is not always achieved nor in clinical practice neither in clinical trials. For instance, in a recent study in acute migraine ${ }^{4}$, the pain freedom at $2 \mathrm{~h}$ ranged from $17.2 \%$ to $31.3 \%$ with active treatments, and it was $9.6 \%$ with placebo. Values of pain relief at $2 \mathrm{~h}$ were from $49.8 \% \%$ to $56.4 \%$ and only $27.7 \%$ with placebo. These values were very similar to those obtained in our meta-analysis, i.e. $28.6 \%$ of pain relief and $8.8 \%$ of pain freedom.

The main objective of our paper was to analyze the significance of placebo effect differences according with clinical trials methodology independently of all the other variables (disease, population and even outcomes). If we assume that methodology makes differences in placebo results, then we might also assume that some aspects associated to clinical practice may influence the therapeutic results of any given treatment in migraine. We consider that our objective was reached but we acknowledge contributions like that of Dr. Tfelt-Hansen which helps to clarify further our results. 


\section{References}

${ }^{1}$ Macedo A, Farré M, Baños J-E. A meta-analysis of the placebo response in acute migraine and how this response may be influenced by some characteristics of clinical trials. Eur J Clin Pharmacol 2006; 62: 161-172.

2 Committee for medicinal products for human use (CHMP). Guideline on clinical investigation of medicinal products for the treatment of migraine. Doc. Ref. CPMP/EWP/788/01 Rev. 1. European Medicines Agency, London, 24 January 2007.

3 Tfelt-Hansen P, Block G, Dahlöf C, Diener HC, Ferrari MD, Goadsby PJ, Guidetti V, Jones B, Lipton RB, Massiou H, Meinert C, Sandrini G, Steiner T, Winter PB; International Headache Society Clinical Trials Subcommittee. Guidelines for controlled trials of drugs in migraine: second edition. Cephalalgia. 2000;20:765-786.

${ }^{4}$ Ho TW, Ferrari MD, Dodick DW, Galet V, Kost J, Fan X, Leibensperger H, Froman S, Assaid C, Lines C, Koppen H, Winer PK. Efficacy and tolerability of MK-0974 (telcagepant), a new oral antagonist of calcitonin gene-related peptide receptor, compared with zolmitriptan for acute migraine: a randomised, placebocontrolled, parallel-treatment trial. Lancet 2008;372:2115-23. 